\title{
Irrigation with water deficit applying magnetic water on scarlet eggplant
}

\author{
Cássio de Castro Seron ${ }^{1}$, Roberto Rezende ${ }^{1}$, Marcelo Zolin Lorenzoni ${ }^{2}$, Álvaro Henrique \\ Cândido de Souza ${ }^{1}$, Antônio Carlos Andrade Gonçalves ${ }^{1}$, Reni Saath ${ }^{1}$ \\ ${ }^{1}$ Universidade Estadual de Maringá, Campus de Maringá, Maringá, Paraná, Brasil. E-mail: cassio.seron@uems.br, \\ rrezende@uem.br, alvarohcs@hotmail.com, acagoncalves@uem.br, rsaath@uem.br \\ ${ }^{2}$ Instituto Federal Goiano, Campus Posse, Posse, Goiás, Brasil. E-mail: marcelorenzoni@ hotmail.com \\ Received: 29/07/2019; Accepted: 15/10/2019.
}

\section{ABSTRACT}

The work aimed to evaluate the effect of irrigation with magnetically treated water on development, growth, and yield of the scarlet eggplant (Solanum gilo Raddi) cv. Morro Grande, in two growing seasons (autumn and spring). A completely randomized design in a $3 \times 2$ factorial scheme with three replications for the first growing season and $2 \times 2$ with five replications for the second growing season was used. Each experimental unit consisted of four plants spaced $0.75 \mathrm{~m}$ between plants and $1.00 \mathrm{~m}$ between rows. Factors consisted of irrigation using magnetically treated water, untreated water, three replacement of the crop evapotranspiration $(50 \%, 75 \%$, and $100 \%$ ETc) for the first growing season and two replacement of the crop evapotranspiration (75\% and $100 \%$ ETc) for the second growing season. Stem diameter (millimeters), plant height (centimeters), shoot dry matter (grams), first flower and fruit (accumulated degree-days), number of fruits, fruit yield per plant (grams), and average fruit mass (grams) were evaluated. The water with magnetic treatment provided better results for the development variables, first flower, and first fruit in the second growing season. However, for the variables, stem diameter, plant height, shoot dry matter, fruit yield, and number of fruits, only the replacement irrigation depth factor obtained higher values for the $100 \%$ ETc than water-deficit treatments.

Keywords: Scarlet eggplant, magnetically treated water, deficit irrigation, and irrigation technology.

\section{Irrigação com déficit hídrico aplicando água tratada magneticamente na cultura do jiló}

\section{RESUMO}

Objetivou-se com este trabalho avaliar o efeito da irrigação com água modificada magneticamente no desenvolvimento, crescimento e produção da cultura do jiló (Solanum gilo Raddi), cultivar Morro Grande, em dois ciclos de cultivo (outono e primavera). Foi utilizado o delineamento inteiramente casualizado em esquema fatorial $3 \times 2$ com três repetições para o primeiro ciclo e $2 \times 2$ com cinco repetições para o segundo ciclo. Cada unidade experimental foi composta por quatro plantas espaçadas em $0,75 \mathrm{~m}$ entre plantas e $1,00 \mathrm{~m}$ entre linhas. Os fatores consistiram na irrigação utilizando água tratada magneticamente, água sem tratamento magnético, três reposições de lâminas de irrigação para o primeiro ciclo $(50 \%, 75 \%$ e $100 \%$ ETc) e duas reposições de lâminas de irrigação ( $75 \%$ e 100\% ETc) para o segundo ciclo. Foram avaliadas as variáveis diâmetro de caule (milímetros), altura de planta (centímetros), massa seca da parte aérea (gramas), primeira inflorescência e frutificação, número de frutos (graus dias acumulados), massa fresca de frutos por planta (gramas) e massa média de frutos (gramas). A água tratada magneticamente proporcionou melhores resultados para as variáveis de desenvolvimento, primeira inflorescência e primeira frutificação no segundo ciclo de cultivo. Entretanto, para as variáveis crescimento e produção, diâmetro de caule, altura de planta, massa seca da parte aérea, massa fresca de frutos e número de frutos, somente o fator lâmina de reposição obteve valores maiores para a lâmina de $100 \%$ em comparação aos tratamentos com déficit hídrico.

Palavras-chave: Jiloeiro, água tratada magneticamente, irrigação com déficit e tecnologia para a irrigação. 


\section{Introduction}

Originally from India or Africa and introduced in Brazil by the slaves in the 17th century, with a production of 79 thousand tons throughout the national territory, and Rio de Janeiro responsible for most of the production in the country (30\%), followed by Minas Gerais, São Paulo and Espírito Santo (IBGE, 2017), the scarlet eggplant (Solanum gilo Raddi) is a typically tropical vegetable with fruit, with high heat demand. Its growth is performed by transplanting seedlings obtained from seeds, and its yields range from 20 to $60 \mathrm{t} \mathrm{ha}^{-1}$ (Pinheiro et al., 2015).

Low temperatures limit yield, especially up to 35 days after germination (Carvalho et al., 2013). For this reason, its growth in a protected environment is advantageous as it improves weather conditions in periods of low temperature; another advantage is that since there is no rainfall directly on the plants, the efficiency of phytosanitary management increases (Filgueira, 2013).

It is essential to know the behavior of each crop due to the different applications of water in its development stages, of higher consumption of water and nutrients. In this way, it is possible to define which irrigation depth is most suitable to be applied in each crop. Adjusting a crop water needs prevents excess or lack of water, which can lead to decline in production (Bernardo et al., 2019).

In vegetable production it is necessary to have advanced criteria and techniques, making use of innovative technologies that promote higher productivity with less use of resources and inputs, not only for the agricultural development achieved in recent years, but also for the important place of production, and food consumption worldwide (Prohens and Nuez, 2008). An innovative technology that has been used to increase crop growth is the implementation of magnetic fields in irrigation water, with proven results in growing and developing crops such as bell pepper (Nimmi and Madhu, 2009), soybean, and corn (Kataria et al., 2015).

The magnetization consists of the generation of a magnetic field, through magnets, inside reservoirs, promoting a molecular reorganization in the liquids deposited in them. According to advocates of the technique, the lines of force generated by the magnets reach the molecules of the liquids and minerals contained in them, promoting a slight physicochemical change. This change gives liquids special characteristics, which provide better assimilation by the organism (Mendonça et al., 2008).

Mahmood and Usman (2014), using magnetically treated water, reported this treatment could increase nutrient absorption and, consequently, increase biomass production in different crops, and this technology can improve water and nutrient utilization efficiency.
According to studies by Khoshravesh et al. (2011), magnetized water used for localized irrigation resulted in higher soil moisture compared to conventional water, and magnetically treated water irrigation could be used to increase irrigation intervals, which would result in more efficient irrigation.

Surendran et al. (2016) used magnetic water treatment on eggplant cultivation and obtained an increase in plant height, leaf number, leaf area, and individual fruit weight, and especially yield increase of 25.8 and $17.0 \%$ under normal and saline water conditions, respectively.

This work aimed to evaluate the effectiveness of the use of magnetically treated water on the growth, development, and production of scarlet eggplant, thus bringing new information for producers to adopt this technology.

\section{Material and Methods}

The experiments were carried out in a protected environment at the Technical Center of Irrigation (CTI) of the State University of Maringá, Maringá, Paraná, at $23^{\circ} 25^{\prime} 57^{\prime \prime S}, 51^{\circ} 57^{\prime} 08^{\prime \prime} \mathrm{W}$ and altitude of $510 \mathrm{~m}$, during spring/summer and autumn/winter.

The protected environment used has a structure composed of an arched roof, consisting of galvanized pipes $30 \mathrm{~m}$ long, $7 \mathrm{~m}$ wide, and $2.5 \mathrm{~m}$ in height. The sides were wrapped with anti-aphid mesh with a $0.25 \mathrm{~m}$ high masonry skirting board. The ceiling is covered with 150-micron thick low-density polyethylene plastic film and anti - UV treatment.

The climate of the region, according to the Köppen classification, is of the Moist Mesothermal Cfa type, characterized by abundant summer rains and dry winters, with annual rainfall close to $1500 \mathrm{~mm}$. The average minimum and maximum air temperatures are $10.3{ }^{\circ} \mathrm{C}$ and $33.6{ }^{\circ} \mathrm{C}$, respectively. The average annual air temperature is $21.8{ }^{\circ} \mathrm{C}$, and the annual average relative air humidity is $66 \%$ (Alvares et al., 2013).

The soil of the experimental area is classified as Nitossolo Vermelho distroférrico (Embrapa, 2018) or Alfisol. The soil chemical properties at depth up to 0.20 $\mathrm{m}$ for both growing seasons are shown in Table 1 .

The fertilization and liming were based on the recommendation proposed by Trani (2014) for vegetables grown in a protected environment. Liming was performed 30 days before seedling transplantation, at the rates of $3640 \mathrm{~kg} \mathrm{ha}^{-1}$ and $715 \mathrm{~kg} \mathrm{ha}^{-1}$, aiming to reach $75 \%$ of base saturation for the first and second growing season, respectively, and fertilization was divided into transplantation (basal) and topdressing. Phosphorus (P) application was performed before the crop was implanted, and nitrogen $(\mathrm{N})$ and potassium $(\mathrm{K})$ fertilization was performed before planting and 
topdressing. The sources used were simple superphosphate for $\mathrm{P}_{2} \mathrm{O}_{5}$, urea for $\mathrm{N}$, and potassium chloride for $\mathrm{K}_{2} \mathrm{O}$.

The cultivar Morro Grande was used. This cultivar has indeterminate growth, round fruits of bright dark green color, with an approximate diameter of 4 to 7 centimeters.

The seedlings were produced in 50-cell plastic trays, filled with commercial coconut fiber substrate, and with one seed per cell. The transplantation was performed at 18 and 33 days after sowing (November 22, 2017, and June 20, 2018) for the first and second growing season, respectively.

The irrigation system consisted of a $0.5 \mathrm{hp}$ pump set, two reservoirs (one $1000 \mathrm{~L}$ and one $500 \mathrm{~L}$ ), a gate valve, and a disc filter. From the pump, a $50 \mathrm{~mm}$ diameter PVC mainline was issued that ran through the protected environment to the full extent in which the lateral lines were installed.

Each seedbed contained a 16-mm polyethylene pipe $3 \mathrm{~m}$ long with 11 drippers (lateral lines). At the beginning of each line was installed a butterfly valve for system operation. The installed drippers were selfcompensating, with $4 \mathrm{~L} \mathrm{~h}^{-1}$ flow at $15 \mathrm{MWC}$ working pressure, controlled with a glycerin pressure gauge located in the system control head.

After the irrigation system was assembled, the distribution uniformity was determined. The uniformity test was performed on all lines of the experiment. With the flow of each dripper, the calculation of the Christiansen uniformity coefficient (CUC) was performed, whose value was $96.8 \%$, considered excellent according to the classification proposed by Frizzone et al. (2012).

The treatments applied in the first growing season were the replacement of the crop evapotranspiration, 50, 75 , and $100 \%$ ETc and by using water with magnetic treatment (MTW) and water without magnetic treatment (WMT), with three replications, totaling 18 experimental units. For the second experiment, the treatments were the replacement of the crop evapotranspiration, 75 and $100 \% \mathrm{ETc}$, and the use of water with magnetic treatment (MTW) and water without magnetic treatment (WMT), with five replications, totaling 20 experimental units.

It was decided not to apply the $50 \%$ ETc replacement treatment in the second growing season, since the plants have reduced growth and low yield when compared to the 75 and $100 \%$ ETc, even with the MTW treatment in the first growing season.

The magnetic treatment of the water was made using a Sylocimol Residence magnetizer (Timol manufacture and sale of magnetics products), with a treatment capacity of $1000 \mathrm{~L}$ of water per hour. For standardization and according to the existing structure, the equipment was allocated to the center of a plastic box with a capacity of $1000 \mathrm{~L}$, where it was exposed for at least 24 hours, the time adopted to ensure the standardization of treatment. For the water without magnetic treatment, another $500 \mathrm{~L}$ reservoir was used, which had no contact with the magnetic field generated by the magnet.

The $\mathrm{ET}_{0}$ calculation was performed using the Penman-Monteith-FAO equation (Allen et al., 1998). The necessary data were obtained from the Campbell automatic weather station, installed inside and in the center of the protected environment. The crop coefficient (Kc) of the crop used was estimated according to Doorenbos and Kassam (1994), confirmed by Marouelli et al. (2001).

The Kc of scarlet eggplant has two periods, growth and stabilization, starting at 0.50 over 30 days from transplanting, increasing for 30 days and stabilizing at 1.10 until the end of the species life cycle, with 150 days for the first growing season, and 180 days for the second growing season.

The existing station was set to collect data every 2 seconds and make the average of each variable available at 30 min intervals. Next to the station was a CR1000 data logger to store the data. Crop evapotranspiration values were determined by the product of reference evapotranspiration $\left(\mathrm{ET}_{0}\right)$ by the crop coefficient $(\mathrm{Kc})$ and expressed in millimeters per day $\left(\mathrm{mm} \mathrm{day}^{-1}\right)$.

Each experimental unit consisted of four plants spaced at $0.75 \mathrm{~m}$, and the central plants were evaluated, considering the first and the last as the border, arranged $0.37 \mathrm{~m}$ from the sideline.

Because it is a protected environment, the water balance comes down to the irrigation depth minus the ETc, because there is no rain within the protected environment. Due to the characteristic of the irrigation system, the application intensity in each plot was equal to $22.80 \mathrm{~mm} \mathrm{~h}^{-1}$, equivalent to $0.38 \mathrm{~mm} \mathrm{~min}^{-1}$ irrigation.

The evaluated growth components were plant height (PH), stem diameter (SD), and shoot dry matter (SDM) in the two central plants, and the plants of the extremities were considered as border.

On the same day, the plant height was measured with the aid of a graduated ruler, and the stem diameter was measured with the aid of a digital caliper with 0.01 $\mathrm{mm}$ precision. The evaluations were carried out fortnightly until the end of each growing season.

Shoot dry mass was obtained by drying the plant material in a forced air circulation oven for 72 hours at $65^{\circ} \mathrm{C}$ and then weighing it on a precision scale $(0.01 \mathrm{~g})$.

The development data of the evaluated plants were the occurrence of the first flower and the first fruit, which were shown as accumulated degree-days (ADD) so that the comparisons between the treatments could be made. 
Table 1. Result of soil chemical analysis of the experimental area for the first and second growing season. Analysis performed by the Soil Analysis Laboratory of the Sindicato Rural de Maringá.

\begin{tabular}{|c|c|c|c|c|c|c|c|c|c|c|}
\hline \multicolumn{11}{|c|}{$1^{\circ}$ Growing season } \\
\hline \multicolumn{2}{|c|}{$\mathrm{pH}$} & OM & $\mathrm{P}$ & $\mathrm{K}^{+}$ & $\mathrm{Ca}^{+2}$ & $\mathrm{Mg}^{+2}$ & $\left(\mathrm{H}^{+}+\mathrm{Al}^{3+}\right)$ & CEC & SB & BS \\
\hline $\mathrm{H}_{2} \mathrm{O}$ & $\mathrm{CaCl}_{2}$ & $\mathrm{~g} \mathrm{dm}^{-3}$ & & \multicolumn{6}{|c|}{$\mathrm{cmol}_{\mathrm{c}} \mathrm{dm}^{-3}$} & $\%$ \\
\hline 5.00 & 4.50 & 9.86 & 2.82 & 0.08 & 1.11 & 1.05 & 4.78 & 7.02 & 2.24 & 31.92 \\
\hline \multicolumn{11}{|c|}{$2^{\circ}$ Growing season } \\
\hline \multicolumn{2}{|c|}{$\mathrm{pH}$} & OM & $\mathrm{P}$ & $\mathrm{K}^{+}$ & $\mathrm{Ca}^{+2}$ & $\mathrm{Mg}^{+2}$ & $\left(\mathrm{H}^{+}+\mathrm{Al}^{3+}\right)$ & CEC & SB & BS \\
\hline $\mathrm{H}_{2} \mathrm{O}$ & $\mathrm{CaCl}_{2}$ & $\mathrm{~g} \mathrm{dm}^{-3}$ & & \multicolumn{6}{|c|}{$\mathrm{cmol}_{\mathrm{c}} \mathrm{dm}^{-3}$} & $\%$ \\
\hline 6.10 & 5.40 & 10.67 & 16.78 & 0.43 & 3.98 & 1.43 & 2.64 & 8.48 & 5.48 & 68.87 \\
\hline
\end{tabular}

This method is used to relate air temperature and plant growth, defined as the sum of temperatures above the minimum condition required for the plant to complete the different development subperiods from the study between maximum, minimum, lower and upper base temperatures of crop, which was considered as $16^{\circ} \mathrm{C}$ and $35^{\circ} \mathrm{C}$, and using the method proposed by Villa Nova et al. (1972) to calculate the degree-days daily, later adding the values for the desired period.

The yield was obtained by weighing the fruits at harvest point, dark green color, and diameter greater than four centimeters. The adopted harvesting point followed the recommendations of Pinheiro et al. (2015). The weekly harvest started at 80 and 110 DAT and lasted until the end of the experiment, at 140 and 175 DAT for the first and second growing season, respectively. Even though the scarlet eggplant has undetermined growth habit, after 110 and 175 days after transplanting began to senescence and it was decided to interrupt the harvest to evaluate shoot dry matter.

The experiment was conducted in a completely randomized design, with a $3 \times 2$ and $2 \times 2$ factorial scheme with three and five replications for the first and second growing season, respectively, factor 1 - irrigation depths (D) and factor 2 - water treatment (W). Homoscedasticity and error normality tests were applied to the response variables under study to meet the basic assumptions of variance analysis (Ferreira, 2014).

\section{Results and Discussion}

Most daily maximum and minimum temperatures were higher than the optimum temperature for the first growing season (Figure 1). The average daily temperatures observed in the second growing season were, on average, lower than those of the first growing season, and had values below the optimal temperature range, which is around 26 to $28{ }^{\circ} \mathrm{C}$, according to Pinheiro et al. (2015).

As it is a hot climate plant and very demanding in high temperature, the most suitable planting season for scarlet eggplant is between September and February, and it is also grown throughout the year; however, in low altitude regions, since they have mild winter, as the species is susceptible to cold (Pinheiro et al., 2015).

Due to the climatic characteristics, the increase of 40 days from the first to the second growing season in the conduction of the crop was necessary to the plant reach its yield potential because the radiation and temperature of second growing season were lower than the first growing season. Also, since the cultivation was carried out under protected environment conditions, the maintenance of a higher temperature helped to increase this period.

The difference between the accumulated irrigation depth in the treatments related to the replacement of crop evapotranspiration tended to increase over time (Figure 2). Up to 20 days after transplanting, a period adopted for the plants to stabilize in the soil, for subsequent application of deficit treatment, besides the treatment without water deficit $(100 \%$ ETc), there was no variation between the applied irrigation depths.

There was no variation of the accumulated water applied between the water with or without magnetic treatment, at the same irrigation depth. Irrigations were performed every two days throughout the first growing season, totaling $182.8 ; 258.3$ and $334.9 \mathrm{~mm}$ of water applied following the $50 \%, 75 \%$, and $100 \%$ irrigation depths, respectively.

In the second growing season, the same irrigation management of the first growing season was adopted, totaling 279.5 and $368.3 \mathrm{~mm}$ of water, applied following the irrigation depths of $75 \%$ and $100 \%$ ETc, respectively.

It can be noted that the irrigation depths applied for both growing seasons were close, however, with different duration periods, corroborating with Pinheiro et al. (2015), who state that with lower temperature conditions, the scarlet eggplant has slow growth and development, thus requiring smaller amounts of water.

According to the analysis of variance (Table 2), it was found that there was no interaction between the water treatment with the irrigation depths for stem diameter, plant height and shoot dry matter, but there was an isolated effect of irrigation depths in the first growing season for all variables. 


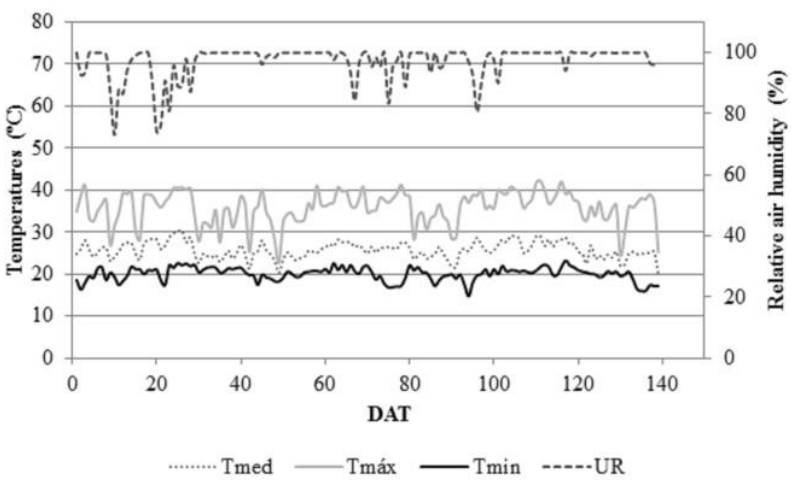

a)

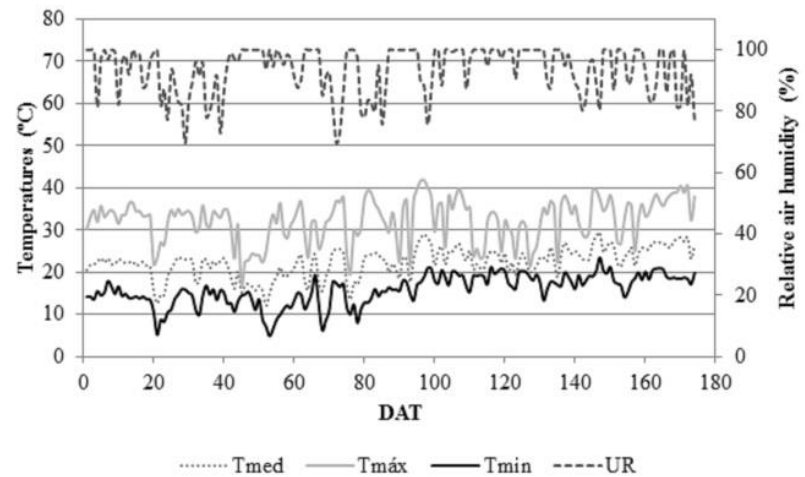

b)

Figure 1. Temperatures and relative air humidity throughout the first (a) and second (b) growing season.

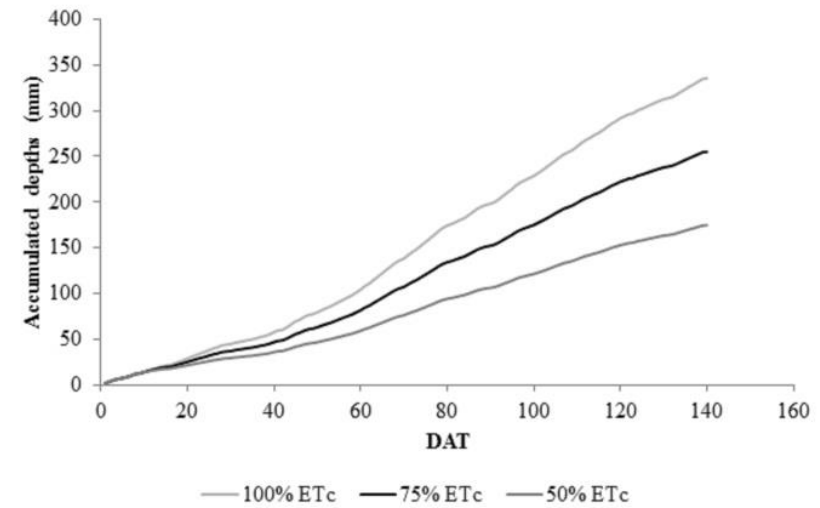

a)

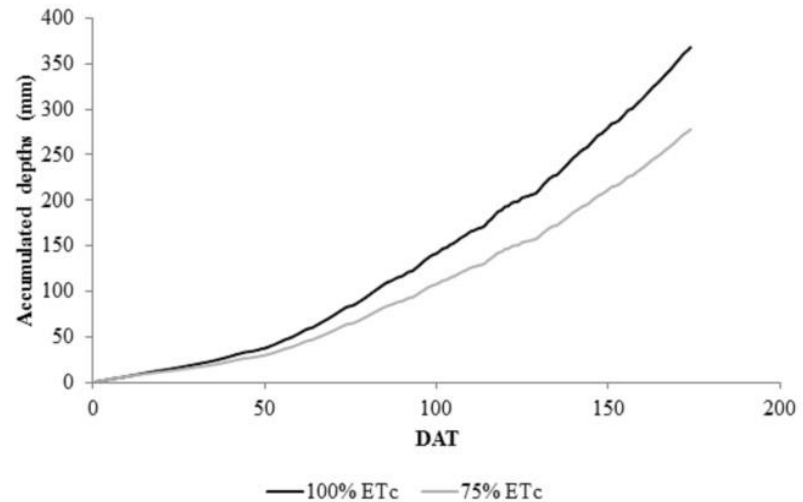

b)

Figure 2. Irrigation depths applied throughout growing seasons: (a) first growing season and (b) second growing season.

Table 2. Summary of analysis of variance for stem diameter (SD), plant height (PH), and shoot dry matter (SDM).

\begin{tabular}{|c|c|c|c|c|c|c|}
\hline \multirow{3}{*}{ Treatment } & \multicolumn{3}{|c|}{$1^{\circ}$ Growing season } & \multicolumn{3}{|c|}{$2^{\circ}$ Growing season } \\
\hline & \multicolumn{6}{|c|}{ F-value } \\
\hline & SD & $\mathrm{PH}$ & SDM & SD & $\mathrm{PH}$ & SDM \\
\hline Water $(\mathrm{W})$ & $0.257^{\mathrm{ns}}$ & $0.026^{\mathrm{ns}}$ & $0.509^{\mathrm{ns}}$ & $2.329^{\mathrm{ns}}$ & $0.168^{\mathrm{ns}}$ & $0.498^{\mathrm{ns}}$ \\
\hline Irrigation depth (D) & $11.676 *$ & $8.221 *$ & $31.904 *$ & $0.721^{\mathrm{ns}}$ & $2.173^{\mathrm{ns}}$ & $0.747^{\mathrm{ns}}$ \\
\hline $\mathrm{W} \times \mathrm{D}$ & $0.622^{\mathrm{ns}}$ & $0.581^{\mathrm{ns}}$ & $2.545^{\mathrm{ns}}$ & $0.143^{\mathrm{ns}}$ & $3.028^{\mathrm{ns}}$ & $1.207^{\mathrm{ns}}$ \\
\hline Average & $25.96 \mathrm{~mm}$ & $206.05 \mathrm{~cm}$ & $351.27 \mathrm{~g}$ & $16.03 \mathrm{~mm}$ & $173.75 \mathrm{~cm}$ & $379.04 \mathrm{~g}$ \\
\hline CV (\%) & 16.06 & 14.98 & 24.47 & 13.78 & 11.48 & 24.61 \\
\hline
\end{tabular}

* significant at $5 \%$ probability; ${ }^{\text {ns }}$ not significant.

The application of different irrigation depths caused significant differences in stem diameter, plant height, and shoot dry matter in the first growing season. From the statistical results obtained, the Tukey test was performed to find the irrigation depth that corresponds to the highest values of the variables mentioned.

It can be observed that for treatments with irrigation depths replacements od 75 and $100 \%$ ETc, there was no significant difference for stem diameter and plant height. However, in the plant height, only the irrigation depth of 50\% ETc was lower than $100 \%$ ETc.
For the shoot dry matter, the irrigation depth of $100 \%$ ETc was superior to all other irrigation depths, with shoot dry matter $137 \%$ higher than irrigation depth of $50 \%$ ETc. These values are favorable for the scarlet eggplant crop to have higher fruit yield, due to the higher biomass accumulation, which can be transformed into fruits. As water is related to cell expansion and division, probably the reduction in growth and biomass accumulation of the scarlet eggplant in the irrigation depth of $50 \%$ ETc was affected by the water deficit to which the plants were subjected (Taiz et al., 2017). 
From the analysis of variance (Table 4), there was no significant interaction between the factors studied $(\mathrm{p}$ $<0.05)$. For water treatment factor, in the second growing season of scarlet eggplant, the flowers and fruits of plants irrigated with water magnetically treated emerged on average, 10 and $11 \%$ earlier than water without magnetic treatment, respectively (Table 5). Regarding the irrigation depths, no significant responses were observed for both factors.

The application of magnetically treated water caused significant differences in the variables of crop development, first flower, and fruit. From the statistical results obtained, the Tukey test was performed to find the lowest values of accumulated degree-days of the growth variables.

Only for the start flowering and fruiting were significant differences observed for the water treatment and the magnetically treated water provided flowers and fruits in a shorter time than the water without magnetic treatment.

As exposed by Pinheiro et al. (2015), the higher temperature promotes the growth of the crop, however, as the growth took place under protected environment conditions, the temperature may have occurred in values higher than recommended and, perhaps, the excess heat interfered negatively for the emergence of the first flower and fruit.

Filgueira (2013) reports that it is possible to grow the scarlet eggplant in the period of lower temperatures, but there will be a decrease in plant development and, consequently, will increase the plant life cycle, which was also observed in this experiment, in the second growing season.

This precocity for flower and fruit had a possible influence on the fruit yield of scarlet eggplant (Table 5), and in the second growing season, higher values than the first were observed, even though there was no significant difference for the water treatment factor. Only for the replacement irrigation depths, the average accumulated degree-days were higher for irrigation depths, $75 \%$, and $100 \%$ ETc in the second growing season.

According to the analysis of variance (Table 6), it was found that there was no interaction between the factors studied for all variables, with only the isolated effect on the applied irrigation depths for fruit yield mass and the number of fruits for both growing seasons $(\mathrm{p}<0.05)$.

The application of the different irrigation depths caused significant differences in the growth variables of the scarlet eggplant. From the statistical results obtained, the Tukey-test was performed to find the irrigation depth that corresponds to the highest values of the variables mentioned.
In the second growing season, the treatment with $50 \%$ replacement of ETc was not evaluated, because besides smaller plants and consequently lower shoot dry matter, the values of fruit yield were $115 \%$ lower than the irrigated plants with full replacement $(100 \%$ ETc) in the first growing season, as shown in Table 3.

However, the irrigation depth of $75 \%$ ETc did not promote a decrease of fruit yield in the first growing season, which allows adopting water-saving strategies without decrease of fruit yield. For the second growing season, the irrigation depth of $100 \%$ ETc resulted in higher fruit yield than the irrigation depth of $75 \%$ ETc. Ambachew et al. (2014) also report the use of watersaving strategies, which may lead to higher yields with a smaller irrigation depth and, consequently, decrease the cost of pumping water.

The average fruit mass values for the second growing season agree with those found by Pinheiro et al. (2015), who found that the average mass value of scarlet eggplant fruits ranges from 20 to 30 grams. Morgado and Dias (1992), evaluating 43 genotypes of scarlet eggplant from the Embrapa Hortaliças germplasm collection, found that the average fruit mass ranged from 19 to $110 \mathrm{~g}$.

Novo et al. (2008), evaluating six cultivars of scarlet eggplant, reported that the average fruit mass of Cardoso cultivar was $51.4 \mathrm{~g}$. However, the variation in average fruit mass was high. For Cardoso, the smallest fruit mass was $23.8 \mathrm{~g}$ and the largest $100.3 \mathrm{~g}$. For the cultivars Bernacci, Esmeralda, and Verde-claro, the smallest and largest fruit mass were 23.6 and $181.9 \mathrm{~g}$; 0.2 and $38.9 \mathrm{~g}$ and 7.10 and $30.5 \mathrm{~g}$, respectively.

For the fruit yield, it was found in the present work, lower values than those found by Pinheiro et al. (2015), who found an average of $1.0 \mathrm{~kg}$ per plant, however, under field conditions, with greater spacing than that used in this study. Novo et al. (2008), evaluating six cultivars of scarlet eggplant under protected environment conditions, found a variation of fruit yield per plant around $320 \%$, ranging from $0.621 \mathrm{~kg}$ to 2.005 $\mathrm{kg}$.

The difference in fruit yield between irrigation depths $(50 \%, 75 \%$ and $100 \%$ ETc) is assigned to the higher values of stem diameter, plant height and shoot dry matter, which were statistically equal and higher for the irrigation depths, $75 \%$ and $100 \%$ ETc (Table 7), showing that the plants of scarlet eggplant with higher biomass produced more fruits and, consequently, had higher fruit yield. Carvalho et al. (2004), studying irrigation depths for eggplant growth, also stated that the severe water deficit harms the crop, so they do not recommend its use. As the eggplant plant is very similar to the scarlet eggplant plant, the same association can be made of the lower fruit yield under severe water deficit. 
Table 3. Stem diameter (SD), plant height $(\mathrm{PH})$, and shoot dry matter (SDM) for the first growing season.

\begin{tabular}{|c|c|c|c|}
\hline \multirow{2}{*}{$\begin{array}{c}\text { Treatment } \\
\text { (Irrigation depth) }\end{array}$} & \multicolumn{3}{|c|}{$1^{\circ}$ Growing season } \\
\hline & $\mathrm{SD}(\mathrm{mm})$ & $\mathrm{PH}(\mathrm{cm})$ & SDM (g) \\
\hline $50 \%$ ETc & $21.62 \mathrm{~A}^{*}$ & $178.83 \mathrm{~A}$ & $204.91 \mathrm{~A}$ \\
\hline $75 \%$ ETc & $26.45 \mathrm{~B}$ & $209.83 \mathrm{AB}$ & $364.66 \mathrm{~B}$ \\
\hline $100 \%$ ETc & $29.80 \mathrm{~B}$ & $229.50 \mathrm{~B}$ & $484.25 \mathrm{C}$ \\
\hline
\end{tabular}

* Averages followed by the same letter do not differ from each other by Tukey's test, at $5 \%$ probability level.

Table 4. Summary of analysis of variance for crop development, accumulated degree-days for the emergence of $1^{\text {st }}$ flower, and $1^{\text {st }}$ fruit.

\begin{tabular}{|c|c|c|c|c|}
\hline \multirow{3}{*}{ Treatment } & \multicolumn{2}{|c|}{$1^{\circ}$ Growing season } & \multicolumn{2}{|c|}{$2^{\circ}$ Growing season } \\
\hline & \multicolumn{4}{|c|}{ F-value } \\
\hline & $1^{\text {st }}$ flower & $1^{\text {st }}$ fruit & $1^{\text {st }}$ flower & $1^{\text {st }}$ fruit \\
\hline Water treatment $(\mathrm{W})$ & $0.053^{\mathrm{ns}}$ & $0.887^{\mathrm{ns}}$ & $7.535 *$ & $6.715 *$ \\
\hline Irrigation depth (D) & $0.613^{\mathrm{ns}}$ & $1.593^{\mathrm{ns}}$ & $0.331^{\mathrm{ns}}$ & $2.399^{\mathrm{ns}}$ \\
\hline $\mathrm{W} \times \mathrm{D}$ & $0.109^{\mathrm{ns}}$ & $0.252^{\mathrm{ns}}$ & $0.098^{\mathrm{ns}}$ & $1.332^{\mathrm{ns}}$ \\
\hline Average (ADD) & 743.66 & 1159.28 & 489.28 & 647.44 \\
\hline $\mathrm{CV}(\%)$ & 19.79 & 17.03 & 8.75 & 10.22 \\
\hline
\end{tabular}

* significant at 5\% probability; ${ }^{\text {ns }}$ not significant. ADD - accumulated degree-days.

Table 5. Average accumulated degree-days for the second growing season.

\begin{tabular}{ccc}
\hline Water treatment & \multicolumn{2}{c}{$2^{\circ}$ Growing season } \\
\cline { 2 - 3 } & $1^{\text {a }}$ flower (ADD) & $1^{\circ}$ fruit (ADD) \\
\hline Water with magnetic treatment & $465.30 \mathrm{~A} *$ & $612.71 \mathrm{~A}$ \\
Water without magnetic treatment & $513.26 \mathrm{~B}$ & $682.17 \mathrm{~B}$ \\
\hline
\end{tabular}

*Averages followed by the same letter do not differ from each other by Tukey's test, at 5\% probability level. ADD - accumulated degree-days.

Table 6. Summary of analysis of variance for fruit yield (FY), number of fruits (NF), and average fruit mass (AFM).

\begin{tabular}{|c|c|c|c|c|c|c|}
\hline \multirow{3}{*}{ Treatment } & \multicolumn{3}{|c|}{$1^{\circ}$ Growing season } & \multicolumn{3}{|c|}{$2^{\circ}$ Growing season } \\
\hline & \multicolumn{6}{|c|}{ F-value } \\
\hline & FY & NF & AFM & FY & $\mathrm{NF}$ & AFM \\
\hline Water treatment $(\mathrm{W})$ & $0.140^{\mathrm{ns}}$ & $0.931^{\mathrm{ns}}$ & $2.675^{\mathrm{ns}}$ & $2.972^{\mathrm{ns}}$ & $0.377^{\mathrm{ns}}$ & $1.947^{\mathrm{ns}}$ \\
\hline Irrigation depth (D) & $57.320 *$ & $41.569 *$ & $3.309^{\mathrm{ns}}$ & $7.646 *$ & $5.200 *$ & $0.208^{\mathrm{ns}}$ \\
\hline $\mathrm{W} \times \mathrm{D}$ & $0.421^{\mathrm{ns}}$ & $1.508^{\mathrm{ns}}$ & $1.455^{\mathrm{ns}}$ & $0.176^{\mathrm{ns}}$ & $0.031^{\mathrm{ns}}$ & $0.252^{\mathrm{ns}}$ \\
\hline Average & $332.52 \mathrm{~g} / \mathrm{p}$ & 21.27 & $15.50 \mathrm{~g} / \mathrm{f}$ & $661.95 \mathrm{~g} / \mathrm{p}$ & 25.90 & $25.76 \mathrm{~g} / \mathrm{f}$ \\
\hline $\mathrm{CV}(\%)$ & 12.36 & 12.63 & 9.27 & 17.65 & 19.69 & 14.45 \\
\hline
\end{tabular}

* significant at $5 \%$ probability; ${ }^{\text {ns }}$ not significant. $\mathrm{g} / \mathrm{p}$ - grams per plant, $\mathrm{g} / \mathrm{f}$ - grams per fruit.

Table 7. Fruit yield (FY) and number of fruits (NF) for the two growing seasons.

\begin{tabular}{|c|c|c|c|c|}
\hline \multirow{2}{*}{$\begin{array}{c}\text { Treatment } \\
\text { (Irrigation depth) }\end{array}$} & \multicolumn{2}{|c|}{$1^{\circ}$ Growing season } & \multicolumn{2}{|c|}{$2^{\circ}$ Growing season } \\
\hline & FY (g per plant) & $\mathrm{NF}$ & FY (g per plant) & $\mathrm{NF}$ \\
\hline $50 \%$ ETc & $186.01 \mathrm{~A}^{*}$ & $13.16 \mathrm{~A}$ & - & - \\
\hline $75 \%$ ETc & $411.55 \mathrm{~B}$ & $26.16 \mathrm{~B}$ & $589.70 \mathrm{~A}$ & $23.30 \mathrm{~A}$ \\
\hline $100 \%$ ETc & $399.99 \mathrm{~B}$ & $24.50 \mathrm{~B}$ & $734.20 \mathrm{~B}$ & $28.50 \mathrm{~B}$ \\
\hline
\end{tabular}

*Averages followed by the same letter do not differ from each other by Tukey's test, at $5 \%$ probability level.

There were no significant differences between water magnetically treated and water without magnetic treatment in both growing seasons, contrary to the studies by Nimmi and Madhu (2009), Kataria et al. (2015) and Harari and Lin (1989), who tested magnetically treated water on bell pepper, soybean, corn and melons, in which there was an increase in production. However, Ospina-Salazar et al. (2018) reported that not all plants have the same positive response when subjected to irrigation with magnetically treated water.

For the scarlet eggplant, the same results were observed, since only flowering and fruiting occurred earlier when magnetically treated water was used, reinforcing the statement by Ospina-Salazar et al. (2018) that there may be different responses to the use of magnetically treated water depending on the crop under study. 


\section{Conclusions}

The magnetically treated water favored the plants in their development, reducing the time for flowering and fruiting.

Irrigation with the replacement of $75 \%$ ETc provided fruit yield values equal to replacement of $100 \%$ ETc.

\section{Bibliographic References}

Allen, R.G., Pereira, L.S., Raes, D., Smith, M., 1998. Crop evapotranspiration: guidelines for computng crop water requirements. FAO Irrigation and Drainage Paper 56, Rome.

Alvares, C.A., Stape, J.L., Sentelhas, P.C., Gonçalves, J.L.M., Sparovek, G., 2013. Koppen's climate classification map for Brazil. Meteorologische Zeitschrift, 22(6), 711-728.

Ambachew, S., Alamirew, T., Melese, A., 2014. Performance of mungbean under deficit irrigation application in the semiarid highlands of Ethiopia. Agricultural Water Management, $136,68-74$

Bernardo, S., Mantovani, E.C., Silva, D.D., Soares, A.A., 2019. Manual de irrigação, nona ed. Viçosa, UFV.

Carvalho, A.D.F., Amaro, G.B., Lopes, J.F., Vilela, N.J., Filho, M.M., Andrade, R., 2013. A cultura do pepino. Embrapa hortaliças, 18 (Circular Técnica 113).

Carvalho, J.A., Santana, M.J., Pereira, G.M., Pereira, J.R.D., Queiroz, T.M., 2004. Níveis de déficit hídrico em diferentes estádios fenológicos da cultura de berinjela (Solanum melongena L.). Revista Brasileira de Engenharia Agrícola, 24(2), 320-327.

Doorenbos, J., Kassam, A.M., 1994. Efeito da água no rendimento das culturas. Estudos FAO, Irrigação e Drenagem, 33. Campina Grande, UFPB.

Embrapa. Sistema Brasileiro de Classificação de Solos, 2018. Centro Nacional de Pesquisa de Solos, quinta ed. Rio de Janeiro, Embrapa Solos.

Ferreira, D.F., 2014. Sisvar: a Guide for its Bootstrap procedures in multiple comparisons. Revista Ciência e Agrotecnologia, 38(2), 109-112.

Filgueira, F.A.R., 2013. Novo manual de oleiricultura: Agrotecnologia moderna na produção e comercialização de hortaliças, terceira ed. Viçosa, UFV.

Frizzone, J.A., Freitas, P.S.L., Rezende, R., Faria, M.A., 2012. Microirrigação: Gotejamento e Microaspersão, primeira ed. Maringá, Eduem.

Harari, M., Lin, I., 1989. Growing muskmelons with magnetically treated water. Water Irrigation Revieus, 9(1), 47.

IBGE - Instituto Brasileiro de Geografia e Estatística, 2017. Censo agropecuário. Rio de Janeiro, IBGE.
Kataria, S., Baghel, L., Guruprasad, K.N., 2015. Acceleration of germination and early growth characteristics of soybean and maize after pretreatment of seeds with static magnetic field. International Journal of Tropical Agriculture, 33(2), 985-992.

Khoshravesh, M., Mostafazadeh-Fard, B., Mousavi1, S.F., Kiani, A.R., 2011. Effects of magnetized water on the distribution pattern of soil water with respect to time intrickle irrigation. Soil Use and Management, 27, 515-522.

Mahmoods, S., Usman, M., 2014. Consequences of magnetized water application maize seed emergence in sand culture. Journal of Agricultural Science and Technology, 16, 47-55.

Marouelli, W.A., Silva, W.L.C., Silva H.R., 2001. Irrigação por aspersão em hortaliças: qualidade da água, aspectos do sistema e método prático de manejo. Brasília, Embrapa.

Mendonça, R.M., Garcia, C.C., Aguiar, J.A., 2008. Uso de água imantada no cultivo de alface em sistema hidropônico NFT. FAZU em Revista, 5, 30-33.

Morgado, H.S., Dias, M.J.V., 1992. Caracterização da coleção de germoplasma de jiló no CNPH/Embrapa. Horticultura Brasileira, 10(2), 86-88.

Nimmi, V., Madhu, G., 2009. Effect of pre-sowing treatment with permanent magnetic field on germination and growth of chilli (Capsicum annum L.). International Agrophysics, 23(2), 195-198.

Novo, M.C.S.S., Trani, P.E., Rolim, G.S., Bernacci, L.C., 2008. Desempenho de cultivares de jiló em casa de vegetação. Bragantia, 67(3), 693-700.

Ospina-Salazar, D.I., Benavides-Bolaños, J.A., ZúñigaEscobar, O., Muñoz-Perea, C.G., 2018. Photosynthesis and biomass yield in tabasco pepper, radish and maize subjected to magnetically treatd water. Corpoica Ciencia Tcnologia Agropecuária, 19(2), 307-321.

Pinheiro, J.B., Pereira, R.B., Freitas, R.A., Melo, R.A.C., 2015. A cultura do jiló. Empresa Brasileira de Pesquisa Agropecurária, Embrapa Hortaliças.

Prohens, J., Nuez, F., 2008. Vegetables II: Fabaceae, Liliaceae, Solanaceae, and Umbelliferae. Handbook of plant breeding, 2, Springer.

Surendran, U., Sandeep, O., Joseph, E.J., 2016. The impacts of magnetic treatment of irrigation water on plant, water and soil characteristics. Agricultural Water Manegement, 178, 21-29.

Taiz, L., Zeiger, E., Moller, I., Murphy, A., 2017. Fisiologia e desenvolvimento vegetal, sexta ed. Porto Alegre, Artmed.

Trani, P.E., 2014. Calagem e adubação para hortaliças sob cultivo protegido. Instituto Agronômico de Campinas, Campinas, $25 \mathrm{p}$.

Villa Nova, N.A., Pedro Júnior, M.J., Pereira, A.R., Ometto, J.C., 1972. Estimativa de graus-dias acima de qualquer temperatura base, em função das temperaturas máxima e mínima. Caderno de Ciências da Terra, 30, 1-8. 